\title{
FAKTOR-FAKTOR YANG BERHUBUNGAN DENGAN PERILAKU SEKSUAL PADA SISWA SMAN 1 LHOKSEUMAWE TAHUN 2009
}

\author{
Harvina Sawitri ${ }^{1}$ Yuziani $^{2^{*}}$ \\ ${ }^{1}$ Bagian Ilmu Kesehatan Masyarakat, Fakultas Kedokteran, \\ Universitas Malikussaleh, Aceh Utara, Indonesia \\ ${ }^{2}$ Bagian Farmakologi, Fakultas Kedokteran, Universitas Malikussaleh, Aceh Utara, Indonesia \\ *Corresponding author : yuziani_twins@yahoo.co.id
}

\begin{abstract}
Abstrak
Remaja SMA merupakan remaja dalam masa yang penuh gejolak dalam mencari identitas diri dan perkembangan seksual mereka. Proporsi perilaku berisiko seksual pada remaja termasuk tinggi. Tujuan dilakukan penelitian ini adalah untuk mengetahui faktor-faktor yang berhubungan dengan perilaku seksual pada siswa SMAN 1 Lhokseumawe. Penelitian ini dilakukan dengan desain cross sectional, jumlah sampel sebanyak 50 siswa, menggunakan kuesioner dan derajat kepercayaannya $90 \%$. Variabel yang diteliti adalah pendidikan orangtua, pekerjaan orangtua, pengaruh media, pengaruh teman dan komunikasi dengan orangtua. Hasil dari penelitan ini adalah komunikasi dengan orangtua $(p=0,064)$ mempunyai hubungan yang bermakna dengan perilaku seksual, sedangkan pendidikan orangtua, pekerjaan orangtua, pengaruh media dan pengaruh teman tidak mempunyai hubungan yang bermakna dengan perilaku seksual. Orangtua yang melakukan komunikasi yang baik dengan anak menyebabkan anak tidak mempunyai persepsi yang salah tentang masalah seksualitasnya.
\end{abstract}

kata kunci : perilaku seksual, komunikasi dengan orang tua, perilaku bermasalah

\section{Factor Associated With Sexual Behavior at SMAN 1 Lhokseumawe Students in 2009}

\begin{abstract}
High school teenagers are adolescence with period full of sexual risk and the proportion of risky sexual behaviors in adolescents is high. The purpose of study was to determine the factors associated with sexual behavior on students of SMAN 1 Lhokseumawe. This research was conducted with a cross-sectional design, the total sample is 50 students, using a questionnaire and the degree of trust of is $90 \%$. Variables studied were parent's education, parent's job, media influence, influence of friends and communication with parents. Results of this research is communication with parents $(p=0.064)$ had a significant association with sexual behavior, while the parents 'education, parents' job, tmedia influence and influence of friends did not have a significant association with sexual behavior. Parents who do good communication with their children would not cause the children to have the wrong perception about sexuality issues.
\end{abstract}

Keyword: sexual behavior, communication with parents, adolescent mischief 


\section{Pendahuluan}

Remaja SMA merupakan remaja dalam masa yang penuh gejolak dalam mencari identitas diri dan perkembangan seksual mereka. Menurut para ahli psikologi berkebangsaan Belanda yaitu L.C.T Bigot, Ph. Kohnstam dan B.G Palland mengkategorikan kelompok usia remaja SMA termasuk dalam kelompuk masa pubertas yaitu usia 15-18 tahun. Hurlock berpendapat bahwa masa puber merupakan fase dalam rentang perkembangan anakanak berubah dari makhluk aseksual menjadi mahluk seksual. Salah satu gejala yang muncul pada masa ini adalah preoccupation with seks (mulai timbul minat pada seks). ${ }^{1}$

Survei Demografi Kesehatan IndonesiaKesehatan Reproduksi (SDKI-KR) tahun 2012 melaporkan bahwa dari 100 perempuan berusia 15 - 24 tahun, perempuan yang mengaku setuju dengan perilaku seksual pranikah sebesar 16,9\%. Sedangkan untuk laki-laki, dari 817 orang, yang mengaku setuju dengan perilaku tersebut sebesar 45,5\%.2 Sebuah penelitian yang dilakukan oleh Synovate Research pada September 2004 tentang perilaku seksual remaja di empat kota besar yaitu Jakarta, Bandung, Surabaya dan Medan pada remaja usia 15-24 tahun menunjukan bahwa $44 \%$ responden mengaku pernah mempunyai pengalaman seks di usia 16-18 tahun dan $16 \%$ mengaku pengalaman seks itu sudah dilakukan pada usia 13-15 tahun. Selain itu, rumah menjadi tempat favorit (40\%) untuk melakukan hubungan seks, sisanya $26 \%$ di tempat kos, $26 \%$, di hotel dan $8 \%$ lain-lain. ${ }^{3}$

Secara garis besar faktor-faktor yang berpengaruh terhadap perilaku reproduksi remaja terdiri dari faktor di luar individu dan faktor di dalam individu. Faktor di luar individu adalah faktor lingkungan di mana remaja tersebut berada; baik itu keluarga maupun kelompok sebaya (peer group). Sedang faktor di dalam individu yang cukup menonjol adalah pengetahuan dan sikap permisif dari individu yang bersangkutan. Sementara sikap permisif ini sangat dipengaruhi oleh lingkungan. Dalam suatu kelompok yang tidak permisif terhadap perilaku reproduksi sebelum menikah akan menekan anggotanya yang bersifat permisif. Dengan demikian kontrol sosial akan mempengaruhi sikap permisif terhadap kelompok tersebut. ${ }^{4}$

Hasil penelitian yang dilakukan Soetjiningsih (2006) menunjukkan, makin baik hubungan orang tua dengan anak remajanya, makin rendah perilaku seksual pranikah remaja. Faktor-faktor yang mempengaruhi perilaku seksual pranikah pada remaja paling tinggi adalah hubungan antara orang tua dengan remaja, tekanan teman sebaya, pemahaman tingkat agama (religiusitas), dan eksposur media pornografi. ${ }^{5}$

\section{Metode Penelitian}

Desain penelitian yang digunakan dalam penelitian faktor-faktor yang berhubungan dengan perilaku seksual siswa kelas 2 (dua) SMAN 1 Lhokseumawe-Aceh bulan Juli-November tahun 2009 adalah desain cross sectional dimana hubungan antara paparan dan efek yang diamati secara serentak pada individu-individu dari populasi tunggal, pada suatu saat tertentu. Desain ini dapat mengukur hubungan antara variabel independen dengan perilaku seksual pada waktu yang sama dan dengan populasi yang sama pula sehingga dapat mempersingkat waktu penelitian. Penelitian ini merupakan penelitian kuantitatif.

Populasi penelitian adalah seluruh siswa kelas 2 (dua) SMAN 1 LhokseumaweAceh. Kemudian dari populasi tersebut diambil sampel yang dapat mewakili populasi dengan teknik simple stratified random sampling, dimana dari populasi tadi dipilih secara acak sampai jumlahnya terpenuhi. Besar sampel pada penelitian ini 
adalah 50 siswa dengan derajat kepercayaan (CI) $90 \%$.

\section{Hasil Penelitian}

Gambaran faktor-faktor yang berhubungan dengan perilaku seksual pada SMUN 1 Lhokseumawe dapat dilihat dalam tabel berikut ini

Tabel 1. Gambaran faktor-faktor yang berhubungan dengan perilaku seksual pada SMUN 1 Lhokseumawe

\begin{tabular}{|c|c|c|}
\hline Variabel & Jumlah & $\begin{array}{l}\text { Persentase } \\
\quad(\%)\end{array}$ \\
\hline \multicolumn{3}{|l|}{ Pendidikan Orang Tua } \\
\hline Tidak Sekolah & 0 & 0 \\
\hline SD & 1 & 2 \\
\hline SMP & 1 & 2 \\
\hline SMA & 24 & 48 \\
\hline Sarjana (S1) & 20 & 40 \\
\hline Magister (S2) & 4 & 8 \\
\hline Doktor (S3) & 0 & 0 \\
\hline \multicolumn{3}{|l|}{ Pekerjaan Orang Tua } \\
\hline Pegawai Negeri Sipil & 18 & 36 \\
\hline Pegawai Swasta & 14 & 28 \\
\hline Wirausaha/Pedagang & 12 & 24 \\
\hline Buruh & 0 & 0 \\
\hline Petani & 0 & 0 \\
\hline Dll & 6 & 12 \\
\hline \multicolumn{3}{|c|}{ Sumber Informasi Seksualitas } \\
\hline Buku-buku Porno & 2 & 4 \\
\hline Majalah dan Koran & 10 & 20 \\
\hline Televisi & 11 & 22 \\
\hline Teman & 25 & 50 \\
\hline Orangtua & 0 & 0 \\
\hline Keluarga & 2 & 4 \\
\hline \multicolumn{3}{|c|}{$\begin{array}{l}\text { Frekuensi Komunikasi dengan Orang Tua } \\
\text { tentang Seksualitas }\end{array}$} \\
\hline Sering & 0 & 0 \\
\hline Jarang & 7 & 14 \\
\hline Kadang-kadang & 20 & 40 \\
\hline Tidak Pernah & 23 & 46 \\
\hline \multicolumn{3}{|c|}{$\begin{array}{l}\text { Pengaruh Komunikasi dengan Orangtua } \\
\text { terhadap Informasi Seksualitas }\end{array}$} \\
\hline Sangat berpengaruh & 14 & 28 \\
\hline Tidak berpengaruh & 15 & 30 \\
\hline $\begin{array}{l}\text { Kadang berpengaruh } \\
\text { kadang tidak }\end{array}$ & 21 & 42 \\
\hline
\end{tabular}

Frekuensi dengan Media Cetak yang Mengandung Seksualitas

$\begin{array}{lcc}\text { Sering } & 2 & 4 \\ \text { Jarang } & 12 & 24 \\ \text { Kadang-kadang } & 24 & 48 \\ \text { Tidak Pernah } & 12 & 24 \\ \text { Pengaruh Media Cetak } & & \\ \text { Sangat berpengaruh } & 24 & 48 \\ \text { Tidak berpengaruh } & 4 & 8 \\ \text { Kadang berpengaruh } & 22 & 44 \\ \text { kadang tidak } & \end{array}$

kadang tidak

Komunikasi dengan Teman

Pelajaran

12

Masalah Pacar

$\begin{array}{cc}6 & 12 \\ 16 & 32\end{array}$

Masalah Keluarga

Masalah Seks

Lain-lain

0

2

Pengaruh Teman

Sangat berpengaruh $\quad 18 \quad 36$

$\begin{array}{lll}\text { Tidak berpengaruh } & 2 & 4\end{array}$

Kadang berpengaruh $\quad 30 \quad 60$

kadang tidak

\begin{tabular}{lll}
\hline Total & 50 & 100 \\
\hline
\end{tabular}

Berdasarkan gambaran tabel diatas, $48 \%$ latar belakang pendidikan orang tua siswa adalah SMA, 36\% pekerjaan orang tua siswa adalah Pegawai Negri Sipil (PNS), $50 \%$ siswa mengetahui informasi tentang seksualitas dari temannya, 46\% siswa tidak pernah membicarakan masalah seksualitas dengan orangtua, siswa yang kadangkadang berinteraksi dengan media cetak mengandung seksualitas adalah $48 \%$, 48\% siswa menjawab bahwa media cetak sangat berpengaruh dalam memberikan informasi tentang seksualitas, 52\% siswa membicarakan masalah lain-lain dengan teman (misalnya hobi), 30\% siswa menganggap bahwa temannya kadang berpengaruh kadang tidak baginya dalam mencari sumber informasi seksualitas.

Faktor-faktor yang berhubungan dengan perilaku seksual menggunakan uji chi-square dapat dilihat pada tabel dibawah ini 
Tabel 2. Faktor yang berhubungan dengan perilaku seksual pada SMUN 1 Lhokseumawe

\begin{tabular}{|c|c|c|c|}
\hline \multirow[b]{2}{*}{ Variabel } & \multicolumn{2}{|c|}{ Perilaku Seksual } & \multirow[b]{2}{*}{$p$-value } \\
\hline & $\begin{array}{c}\text { Perilaku Tidak } \\
\text { Bermasalah }\end{array}$ & $\begin{array}{c}\text { Perilaku } \\
\text { Bermasalah }\end{array}$ & \\
\hline \multicolumn{4}{|c|}{ Pendidikan Orang Tua } \\
\hline Rendah & $21(80,8 \%)$ & $5(19,2 \%)$ & 0,151 \\
\hline Tinggi & $15(62,5 \%)$ & $9(37,5 \%)$ & \\
\hline \multicolumn{4}{|l|}{ Pekerjaan Orang Tua } \\
\hline Swasta & $13(72,2 \%)$ & $5(27,8 \%)$ & 0,979 \\
\hline Negeri & $23(71,9 \%)$ & $9(28,1 \%)$ & \\
\hline \multicolumn{4}{|l|}{ Pengaruh Media } \\
\hline Tidak berpengaruh & $21(80,8)$ & $5(19,2)$ & 0,151 \\
\hline Berpengaruh & $15(62,5 \%)$ & $9(37,5 \%)$ & \\
\hline \multicolumn{4}{|l|}{ Pengaruh Teman } \\
\hline Tidak berpengaruh & $25(78,1 \%)$ & $7(21,9 \%)$ & 0,198 \\
\hline Berpengaruh & $11(61,1 \%)$ & $7(38,9 \%)$ & \\
\hline \multicolumn{4}{|c|}{ Komunikasi dengan Orang } \\
\hline \multicolumn{4}{|l|}{ Tua } \\
\hline Buruk & $3(42,9 \%)$ & $4(57,1 \%)$ & 0,064 \\
\hline Baik & $33(76,7 \%)$ & $10(23,3 \%)$ & \\
\hline
\end{tabular}

Berdasarkan data diatas, siswa yang orangtua berpendidikan rendah 19,2\% mempunyai perilaku seksual bermasalah, sedangkan yang orangtua berpendidikan tinggi $37,5 \%$ mempunyai perilaku seksual bermasalah. Hasil uji statistik menunjukkan nilai $p=0,151$ dengan $a=0,1$. Hal ini menunjukkan tidak ada hubungan yang bermakna antara pendidikan orangtua dengan perilaku seksual remaja karena nilai $\mathrm{p}>\mathrm{a}$. Siswa yang orangtua punya pekerjaan swasta $27,8 \%$ mempunyai perilaku seksual bermasalah, sedangkan yang punya pekerjaan pegawai negeri $28,1 \%$ mempunyai perilaku seksual bermasalah. Hasil uji statistik menunjukkan nilai $\mathrm{p}=0,979$ dengan $a=0,1$. Hal ini menunjukkan tidak ada hubungan yang bermakna antara pekerjaan orangtua dengan perilaku seksual remaja karena nilai $\mathrm{p}>\mathrm{a}$. Siswa yang menganggap media tidak berpengaruh 19,2\% mempunyai perilaku seksual bermasalah, sedangkan yang menganggap media berpengaruh $37,5 \%$ mempunyai perilaku seksual bermasalah. Hasil uji statistik menunjukkan nilai $\mathrm{p}=0,151$ dengan $\mathrm{a}=0,1$. Hal ini menunjukkan tidak ada hubungan yang bermakna antara media dengan perilaku seksual remaja karena nilai $\mathrm{p}>\mathrm{a}$. Siswa yang menganggap teman tidak berpengaruh $21,9 \%$ mempunyai perilaku seksual bermasalah, sedangkan yang menganggap teman berpengaruh $38,9 \%$ mempunyai perilaku seksual bermasalah. Hasil uji statistik menunjukkan nilai $\mathrm{p}=0,198$ dengan $a=0,1$. Hal ini menunjukkan tidak ada hubungan yang bermakna antara pengaruh teman dengan perilaku seksual remaja karena nilai $\mathrm{p}>\mathrm{a}$. Siswa yang komunikasi dengan orangtuanya buruk 57,1\% mempunyai perilaku seksual bermasalah, sedangkan yang komunikasi dengan orangtuanya baik 23,3\% mempunyai perilaku seksual bermasalah. Hasil uji statistik menunjukkan nilai $\mathrm{p}=0,064$ dengan $a=0,1$. Hal ini menunjukkan ada hubungan yang bermakna antara komunikasi dengan orangtua dengan perilaku seksual remaja karena nilai $\mathrm{p}<\mathrm{a}$. 


\section{Pembahasan}

Siswa yang orangtua berpendidikan rendah $19,2 \%$ mempunyai perilaku seksual bermasalah, sedangkan yang orangtua berpendidikan tinggi 37,5\% mempunyai perilaku seksual bermasalah. Hasil uji statistik menunjukkan nilai $\mathrm{p}=0,151$ dengan $a=0,1$. Hal ini menunjukkan tidak ada hubungan yang bermakna antara pendidikan orangtua dengan perilaku seksual remaja. Siswa yang orangtua punya pekerjaan swasta 27,8\% mempunyai perilaku seksual bermasalah, sedangkan yang punya pekerjaan pegawai negeri $28,1 \%$ mempunyai perilaku seksual bermasalah. Hasil uji statistik menunjukkan nilai $p=0,979$ dengan $\mathrm{a}=0,1$. Hal ini menunjukkan tidak ada hubungan yang bermakna antara pekerjaan orangtua dengan perilaku seksual remaja. Kondisi sosioekonomi keluarga memberikan pengaruh yang signifikan terhadap aktivitas seksual remaja. Kondisi ini lebih karena individu yang berasal dari keluarga dengan kondisi sosioekonomi sedang dan tinggi memiliki layanan atau fasilitas yang lebih dibandingkan dengan individu dari keluarga dengan sosioekonomi rendah. Mereka memiliki gadget-gadget baru dengan fitur internet dan sosial media yang memudahkan mereka untuk mendapatkan berbagai informasi dan menjalin hubungan sosial secara lebih luas. Mereka juga memiliki uang saku yang cukup sehingga memiliki cukup pulsa untuk melakukan aktivitas yang berkaitan dengan gadget mereka. Kondisi ini tidak berlaku bagi remaja dari keluarga dengan sosioekonomi rendah, meraka hanya memiliki telepon genggam versi lama. Selain itu kondisi sosioekonomi juga membuat penampilan mereka menjadi berbeda. Mereka tampak lebih menarik dengan dandanan yang sedikit lebih berani baik dari sisi pakaian maupun kosmetik, sehingga mereka lebih dini dalam berpacaran. Kondisi inilah yang membuat mereka cenderung melakukan aktivitas seksual pranikah. ${ }^{6}$

Siswa yang menganggap media tidak berpengaruh, 19,2\% mempunyai perilaku seksual bermasalah, sedangkan yang menganggap media berpengaruh 37,5\% mempunyai perilaku seksual bermasalah. Hasil uji statistik menunjukkan nilai $p=0,151$ dengan $a=0,1$. Hal ini menunjukkan tidak ada hubungan yang bermakna antara media dengan perilaku seksual remaja. Hasil penelitian ini berbeda dengan penelitian yang dilakukan Mandey $(2014)^{7}$ dimana terdapat hubungan yang bermakna antara akses ke media pornografi dengan perilaku seksual pranikah berisiko pada mahasiswa di FIS (Fakultas Ilmu Sosial) UNIMA (Universitas Negeri Manado), dengan $p$ value $=0,003$. Menurut Sarwono (2012), banyak faktor yang mempengaruhi perilaku seksual pada remaja salah satunya media sosial (internet). Media sosial adalah bentukbentuk eletronik di mana pengguna membuat komunitas online untuk berbagi informasi, ide, pesan pribadi dan konten lainnya. ${ }^{8}$ Blog, jejaring sosial dan wiki merupakan bentuk media sosial yang paling umum digunakan oleh masyarakat di seluruh dunia. ${ }^{9}$ Media Sosial adalah demokratisasi informasi, mengubah orang dari pembaca konten ke penerbit konten. Hal ini merupakan pergeseran dari mekanisme siaran ke model banyak ke banyak, berakar pada percakapan antara penulis, orang, dan teman sebaya. Berdasarkan defnisi tersebut diketahui unsur-unsur fundamental dari media sosial yaitu pertama, media sosial melibatkan saluran sosial yang berbeda dan online menjadi saluran utama. Kedua, media sosial berubah dari waktu ke waktu, artinya media sosial terus berkembang. Ketiga, media sosial adalah partisipatif. "penonton" dianggap kreatif sehingga dapat memberikan komentar. ${ }^{10}$

Siswa yang menganggap teman tidak berpengaruh $21,9 \%$ mempunyai perilaku 
seksual bermasalah, sedangkan yang menganggap teman berpengaruh 38,9\% mempunyai perilaku seksual bermasalah. Hasil uji statistik menunjukkan nilai $\mathrm{p}=0,198$ dengan $a=0,1$. Hal ini menunjukkan tidak ada hubungan yang bermakna antara pengaruh teman dengan perilaku seksual remaja. Berbeda dengan penelitian Rosdarni,dkk, teman sebaya memberikan pengaruh yang langsung terhadap remaja dalam berperilaku seksual pranikah yang berisiko. Remaja yang memiliki pengaruh dari teman sebaya yang tinggi berpeluang sebesar 1,7 kali untuk melakukan perilaku seksual pranikah yang berisiko dibandingkan remaja yang memiliki pengaruh dari teman sebaya yang rendah. ${ }^{11}$ Remaja yang melakukan perilaku seks pranikah dapat termotivasi oleh pengaruh kelompok (teman sebaya) dalam upaya ingin menjadi bagian dari kelompoknya dengan mengikuti norma- norma yang telah dianut oleh kelompoknya (melakukan perilaku seks pranikah). Selain itu, didorong oleh rasa ingin tahu yang besar untuk mencoba segala hal yang belum diketahui. Pada masa remaja, kedekatan dengan peer- group sangat tinggi karena selain ikatan peer- group menggantikan ikatan keluarga, juga merupakan sumber afeksi, simpati, dan pengertian, saling berbagi pengalaman dan sebagai tempat remaja untuk mencapai otonomi dan independensi. Dengan demikian remaja mempunyai kecenderungan untuk mengadopsi informasi yang diterima oleh temantemannya, tanpa memiliki dasar informasi yang signifikan dari sumber yang lebih dapat dipercaya. ${ }^{12}$

Siswa yang komunikasi dengan orangtuanya buruk $57,1 \%$ mempunyai perilaku seksual bermasalah, sedangkan yang komunikasi dengan orangtuanya baik 23,3\% mempunyai perilaku seksual bermasalah. Hasil uji statistik menunjukkan nilai $p=0,064$ dengan $a=0,1$. Hal ini menunjukkan ada hubungan yang bermakna antara komunikasi dengan orangtua dengan perilaku seksual remaja. Hasil penelitian ini sama dengan Rosdarni, dkk yang menyatakan komunikasi yang jarang antara orangtua dan remaja dalam membahas seksualitas memberikan peluang sebesar 1,4 kali kepada remaja untuk berperilaku seksual pranikah yang berisiko dibandingkan remaja yang sering melakukan komunikasi. ${ }^{11}$ Komunikasi yang dilakukan oleh remaja putri terkait masalah seksual kepada orang tuanya atau komunikasi yang dilakukan oleh orang tua berhasil merubah perilaku remaja terhadap perilaku seksual, dengan berkomunikasi dengan orang tua tentang masalah seksual, remaja bisa menghindarkan diri mereka sendiri dari perilaku seksual yang menyimpang, sesuai dengan teori S-O-R yang beranggapan bahwa organisme menghasilkan perilaku tertentu jika ada stimulus tertentu pula, jadi ketika berkomunikasi orang tua tidak lupa untuk selalu menasehati remaja putri untuk tidak terjerumus ke dalam perilaku seksual yang menyimpang, stimulus ini di terima dengan oleh remaja dan diterapkan di dalam kehidupan sehari - hari, bagaimana mereka berpacaran dengan tidak selalu bersentuhan, tidak melakukan tindakan berciuman, bercumbuan sampai dengan berhubungan seksual. ${ }^{13}$ Hubungan orangtua yang harmonis akan menumbuhkan kehidupan emosional yang optimal terhadap perkembangan kepribadian anak sebaliknya. Orang tua yang sering bertengkar akan menghambat komunikasi dalam keluarga, dan anak akan "melarikan diri“ dari keluarga. Keluarga yang tidak lengkap misalnya karena perceraian, kematian, dan keluarga dengan keadaan ekonomi yang kurang, dapat mempengaruhi perkembangan jiwa anak..$^{14}$ 


\section{Daftar Pustaka}

1. Al mighwar M. Psikologi remaja : petunjuk bagi guru dan orang tua. Bandung: Pustaka setia, 2006.

2. BPS, Kementerian Kesehatan Republik Indonesia, ICF Internasional. SDKI 2012 kesehatan reproduksi remaja laporan pendahuluan. Jakarta: Badan Pusat Statistik, 2012.

3. Susanti F. Menuju Masa Akil Baligh. Jakarta: Sunda Kelapa Pustaka, 2008.

4. Dinas Kesehatan Kabupaten Banyumas. Laporan Tahunan, 2007.

5. Soetjiningsih. Remaja Usia $15-18$ Tahun Banyak Lakukan Perilaku Seksual Pranikah [cited 2009 Jan 6]. Available from: URL: http://www.ugm.ac.id

6. Maimunah Siti. Pengaruh faktor keluarga terhadap perilaku seksual remaja. Seminar Psikologi dan Kemanusiaan; 2015 Hal 359-362; Malang. Malang : Fakultas Psikologi UMM.

7. Skripsi Mandey Frike K. P. Faktorfaktor yang berhubungan dengan perilaku seksual pranikah berisiko pada mahasiswa di Fakultas Ilmu Sosial Universitas Negeri Manado [skripsi]. Manado : Universitas Negeri Manado, 2014.

8. Sarwono S. W. Psikologi Remaja. Jakarta : PT Raja Grafindo Persada, 2012.

9. Skripsi Riswanti HA. Hubungan pengetahuuan tentang media sosial dengan sikap remaja dalam seks bebas pada siswa kelas II di SMAK St. Gabriel Maumere Tahun 2012 [Skripsi]. Maumere; Universitas Nusa Nipa; 2012.
10. Siti N. Pengaruh penggunaan media sosial facebook terhadap perilaku cyberbullying pada siswa SMAN 12 Pekanbaru. Jurnal Fisip. 2014; 1 (2) : 2.

11. Rosdarni, Dasuki Djaswadi, Waluyo Djoko Sumarni. Pengaruh faktor personal terhadap perilaku seksual pranikah pada remaja. Jurnal Kesehatan Masyarakat Nasional 2015; 9 : 214-221.

12. Suwarni L. Monitoring parental dan perilaku teman sebaya terhadap perilaku seksual remaja SMA di kota Pontianak. Jurnal Promosi Kesehatan Indonesia 2009; 4 (2) : 127- 133.

13. Sauri, Achmad. Pengaruh komunikasi antar pribadi orangtua tua terhadap perilaku seksual remaja di SMKN 1 Tenggarong Kutai Kartanegara. Jurnal Ilmu Komunikasi 2014; 2(1) : 349-362.

14. Rohmahwati D.A, Lutfiati, A, Sri M. Pengaruh pergaulan bebas dan vcd porno terhadap perilaku remaja di Masyarakat. 2008 [diakses 2009 Nov 29]. Available from : http://kbi.gemari.or.id/beritadetail.ph p?id=2569. 